УДК 656.13.072.6

\title{
ФОРМУВАННЯ ПОПЕРЕДЖУЮЧИХ ТА КОРИГУВАЛЬНИХ ДІЙ В СИСТЕМІ УПРАВЛІННЯ ЦННІСТЮ ПОСЛУГ ПАСАЖИРСЬКОГО АВТОМОБІЛЬНОГО ТРАНСПОРТУ
}

\author{
Легкий С.А., к.е.н, доцент (АДІ ДВНЗ «ДонНТУ»)
}

\begin{abstract}
На основі аналізу існуючих моделей прочесів попереджуючих та коригувальних дій в системах управління, з використанням процесного підходу та методології IDEF0, для системи управління иінністю послуг пасажирського автомобільного транспорту розроблено моделі процесів попереджуючих та коригувальних дій. Пропоновані прочеси попереджуючих та коригувальних дій базуються на фундаментальних принципах управління та можуть бути використані в інших системах управління.
\end{abstract}

Ключові слова: послуга, цінність, дія попереджуюча, невідповідність, зіставлення, коригування.

\section{ФОРМИРОВАНИЕ ПРЕДУПРЕЖДАЮЩИХ И КОРРЕКТИРУЮЩИХ ДЕЙСТВИЙ В СИСТЕМЕ УПРАВЛЕНИЯ ЦЕННОСТЬЮ УСЛУГ ПАССАЖИРСКОГО АВТОМОБИЛЬНОГО ТРАНСПОРТА}

\author{
Легкий С.А., к.э.н, доцент (АДИ ГВУЗ «ДонНТУ»)
}

\begin{abstract}
На основе анализа существующих моделей процессов предупреждающих $u$ корректирующих действий в системах управления, с использованием прочессного подхода и методологии IDEF0, для системь управления иенностью услуг пассажирского автомобильного транспорта разработаны модели прочессов предупреждающих $и$ корректирующих действий. Предложенные процессы предупреждающих и корректирующих действий базируются на фундаментальных принципах управления и могут быть использованы в других системах управления.
\end{abstract}

Ключевые слова: услуга, ценность, действие предупреждающее, несоответствие, сопоставление, корректирование.

\section{FORMING OF WARNINGS AND CORRECTINGS ACTIONS IS IN CONTROL SYSTEM BY VALUE OF SERVICES OF PASSENGER MOTOR TRANSPORT}

\author{
Legkiy S.A., candidate of Economic Sciences, associate professor \\ (Automobile and Highway Institute SIHE «DonNTU»)
}

The purpose of the article is a ground and development of processes of warnings and correctings actions in control system by the value of services of passenger motor transport. On the basis of analysis of existent models of processes of warnings and correctings actions in control system, with the use of processnogo approach and methodology of functional design of IDEF0, for control system by the value of services of passenger motor transport the models of processes of warnings and correctings actions are developed. The offered processes allow motor transport enterprises in good time to accept administrative decisions on the removal of potential reasons of rejection of actual arguments of value of favour from the planned level and adjustment of actual arguments of value at the exposure of the indicated rejections. We suggest to use for forming of warnings actions a management on indignations, correctings - on rejections. The developed 
processes of warnings and correctings actions can be used in control system by the value of other services taking into account their specific.

Key words: service, value, an action warning, disparity, comparison, adjustment.

Постановка проблеми. Цінність послуг $€$ одним 3 найважливіших чинників забезпечення конкурентоспроможності й ефективності діяльності автотранспортних підприємств. Одним з найважливіших шляхів підвищення іï рівня $є$ створення на підприємствах системи управління цінністю, яка має ефективні попереджуючі та коригувальні управлінські дій, що спрямовані на виявлення та попередження можливих помилок i недоробок. Усе сказане й обумовлює актуальність проблеми наукового обгрунтування i розробки процесів формування попереджуючих та коригувальних дій в системі управління цінністю.

Аналіз останніх досліджень та публікацій. Проведений аналіз останніх досліджень та публікацій [1-3] дозволяє зробити висновок, що на даний момент вчені, що розглядали питання цінності товарів та послуг не приділяють достатньої уваги створенню системи управління цією цінністю, а відповідно й формуванню попереджуючих та коригувальних дій у цій системі. Причина цього полягає у відсутності єдиної точки зору в розумінні сутності й методики визначення цінності [4]. На авіаційному транспорті спробу створення системи управління цінністю послуги здійснила К.О. Калда [5], однак також в пропонованій системі попереджуючі та коригувальні дії вона не застосовує.

Попереджуючі та коригувальні дії передбачені в сфері управління якістю. В цій сфері існує стандарт ISO 9000:2009 [6], в якому визначено терміни «попереджуючі (запобіжні)» та «коригувальні дії». Згідно цього стандарту попереджуюча дія - це дія, яку виконують, щоб усунути причину потенційної невідповідності або іншої потенційно небажаної ситуації, коригувальна дія - це дія, яку виконують, щоб усунути причину виявленої невідповідності або іншої небажаної ситуації.

Також необхідно відзначити, що розроблені попереджуючі та коригувальні дії систем управління якістю для підприємствах різних галузей народного господарства [7-9] не можуть бути без певних перетворень використані для формування попереджуючих та коригувальних дій в системах управління цінністю послуг пасажирського автомобільного транспорту. Ці перетворення стосуються врахування особливостей процесу формування цінності зазначених послуг.

$\begin{array}{ccr}\text { Мета } & \text { статті. } & \text { Обгрунтування та } \\ \text { розробка } & \text { процесів } & \text { формування }\end{array}$
попереджуючих та коригувальних дій в системі управління цінністю послуг пасажирського автомобільного транспорту.

Виклад основного матеріалу. Обгрунтування змісту процесів формування попереджуючих та коригувальних дій в системі управління цінністю послуг пасажирського автомобільного транспорту [10] пропонується здійснювати на основі розробленого процесу іiі формування [11] за допомогою процесного підходу та методології IDEF0 [12]. Також при розробці зазначених дій використовуємо фундаментальні принципи управління, що розроблені в теорії автоматичного управління [13]. В основу попереджуючих дії покладемо принцип компенсації, в основу коригувальних дій принцип зворотного зв'язку.

Пропонована функціональна модель процесу попереджуючих дій в системі управління цінністю послуг пасажирського автомобільного транспорту представлена на рис. 1.

Першим етапом процесу попереджуючих дій в системі управління цінністю є підпроцес збору даних про вимоги споживачів до послуги. «Входом» цього підпроцесу $\epsilon$ інформація про поточні або передбачувані вимоги споживачів до послуги. Враховуючи те, що зазначена інформація представляє собою внутрішні бажання, потреби споживачів, керуючий вплив на зазначений підпроцес здійснюється на підставі маркетингового дослідження. «Виходом» підпроцесу $\epsilon$ набір бажаних параметрів послуги. 


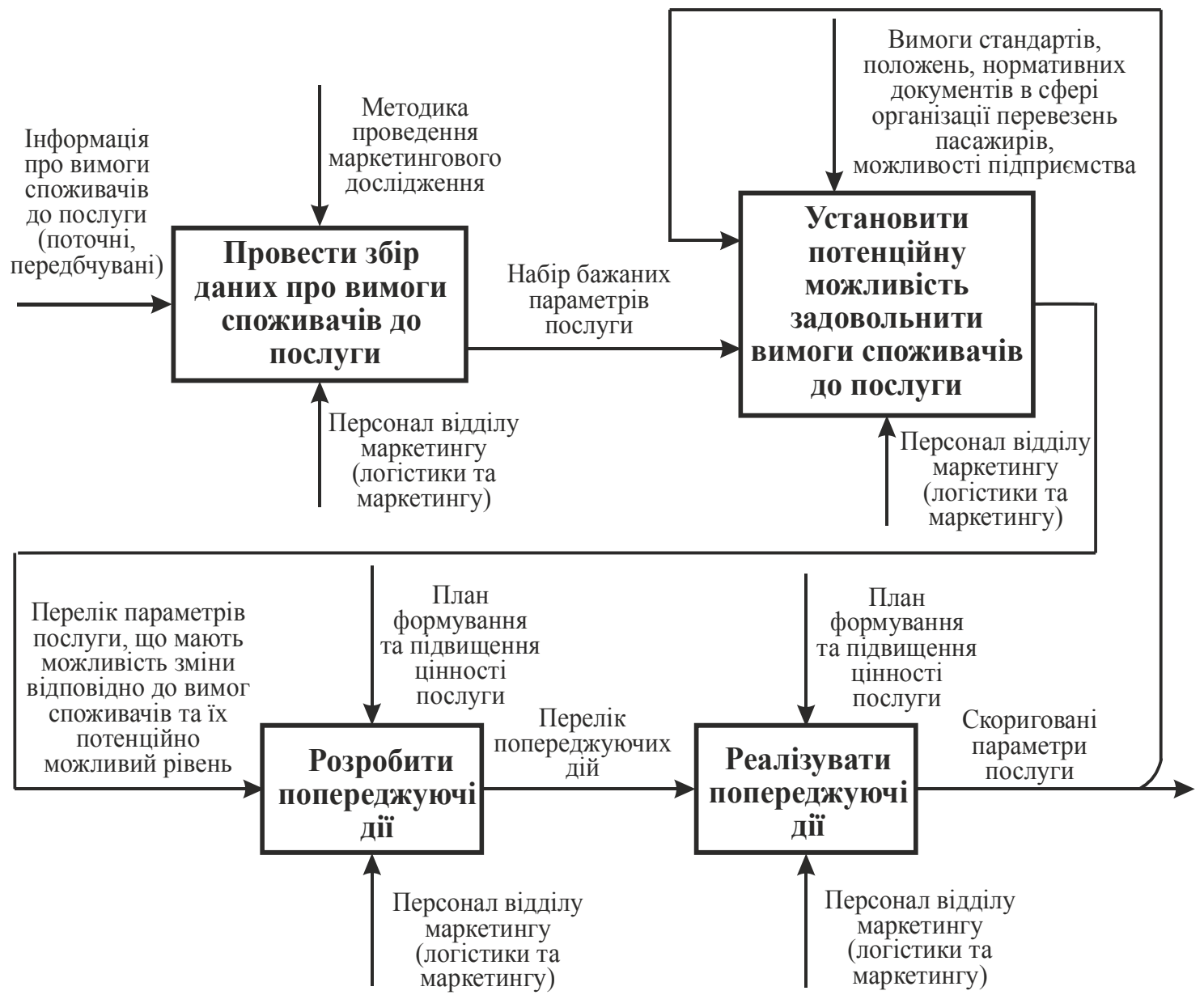

Рис. 1. Функиіональна модель процесу попереджуючих дій в системі управління цінністю послуг пасажсирського автомобільного транспорту

Наступним кроком $є$ установлення потенційної можливості задовольнити вимоги споживачів до послуги при виконанні процесу перевезення пасажирів 3 параметрами послуги, що визначені планом формування та підвищення іiі цінності, який пропонується розробляти згідно [11]. «Входом» цього підпроцесу $є$ «вихід》 попереднього підпроцесу. Управління підпроцесом здійснюється на підставі вимог стандартів, положень, що діють в сфері організації перевезень пасажирів та можливостей автотранспортного підприємства. «Виходом» цього підпроцесу $є$ перелік параметрів послуги, що мають можливість зміни відповідно до вимог споживачів та їх потенційно можливий рівень.

Далі здійснюється розробка попереджуючих дій, спрямованих на забезпечення потенційно можливого рівня параметрів цінності послуги (усунення потенційної невідповідності). «Входом» цього підпроцесу $€$ «вихід》 попереднього підпроцесу. Управління зазначеним підпроцесом здійснюється на підставі плану формування та підвищення цінності послуги. «Виходом» підпроцесу $\epsilon$ перелік попереджуючих дій.

Завершальним етапом попереджуючих дій в системі управління цінністю $є$ реалізація цих дій та оцінка їхньої ефективності. «Входом» цього підпроцесу $є$ «вихід» попереднього підпроцесу. Управління підпроцесом здійснюється на підставі плану формування та підвищення цінності послуги. «Виходом» цього підпроцесу $є$ скориговані параметри послуги, на підставі яких також здійснюється оцінка ефективності попереджуючих дій. Для цього «вихід» підпроцесу реалізації попереджуючих дій $\epsilon$ «входом» підпроцесу установлення потенційної можливості задовольнити вимоги споживачів до послуги. В разі, якщо скориговані параметри послуги відповідають 
потенційно можливому їх рівню (вимогам споживачів), попереджуючі дії вважаються ефективними i послуга надається 3 цими параметрами. В іншому випадку попереджуючі дії вважаються не ефективними та здійснюється їх перегляд.

Пропонована функціональна модель процесу коригувальних дій в системі управління цінністю послуг пасажирського автомобільного транспорту представлена на рис. 2.

Процес коригувальних дій в системі управління цінністю починається з підпроцесу збору даних про фактичні параметри цінності послуги, «входом» якого $є$ інформація про фактичні параметри послуги, рекламації та скарги споживачів. Зазначену інформацію отримують від контрольно-ревізійної служби автотранспортного підприємства. Керуючий вплив на цей підпроцес здійснюється на підставі плану формування та підвищення цінності послуги. «Виходом» підпроцесу $\epsilon$ фактичні параметри послуги, що необхідні для визначення іiї цінності.

Далі виконується обробка зібраних даних, яка полягає в перетворенні фактичних

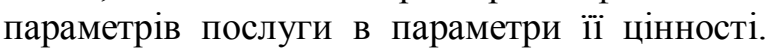
«Входом» цього підпроцесу $є$ «вихід» попереднього підпроцесу. Керуючий вплив на процес обробки даних здійснюється на підставі методики визначення параметрів послуги [14]. Крім того необхідно враховувати, що інформація про такі параметри послуги як санітарно-гігієнічний стан салону; освітлення салону; технічний стан автобусів, що впливає на комфорт поїздки; інформативність; обслуговування у години пік; обслуговування залежно від погодних умов може також поступати у вигляді рекламацій та скарг споживачів. «Виходом» підпроцесу обробки даних $\epsilon$ фактичні параметри цінності послуги.
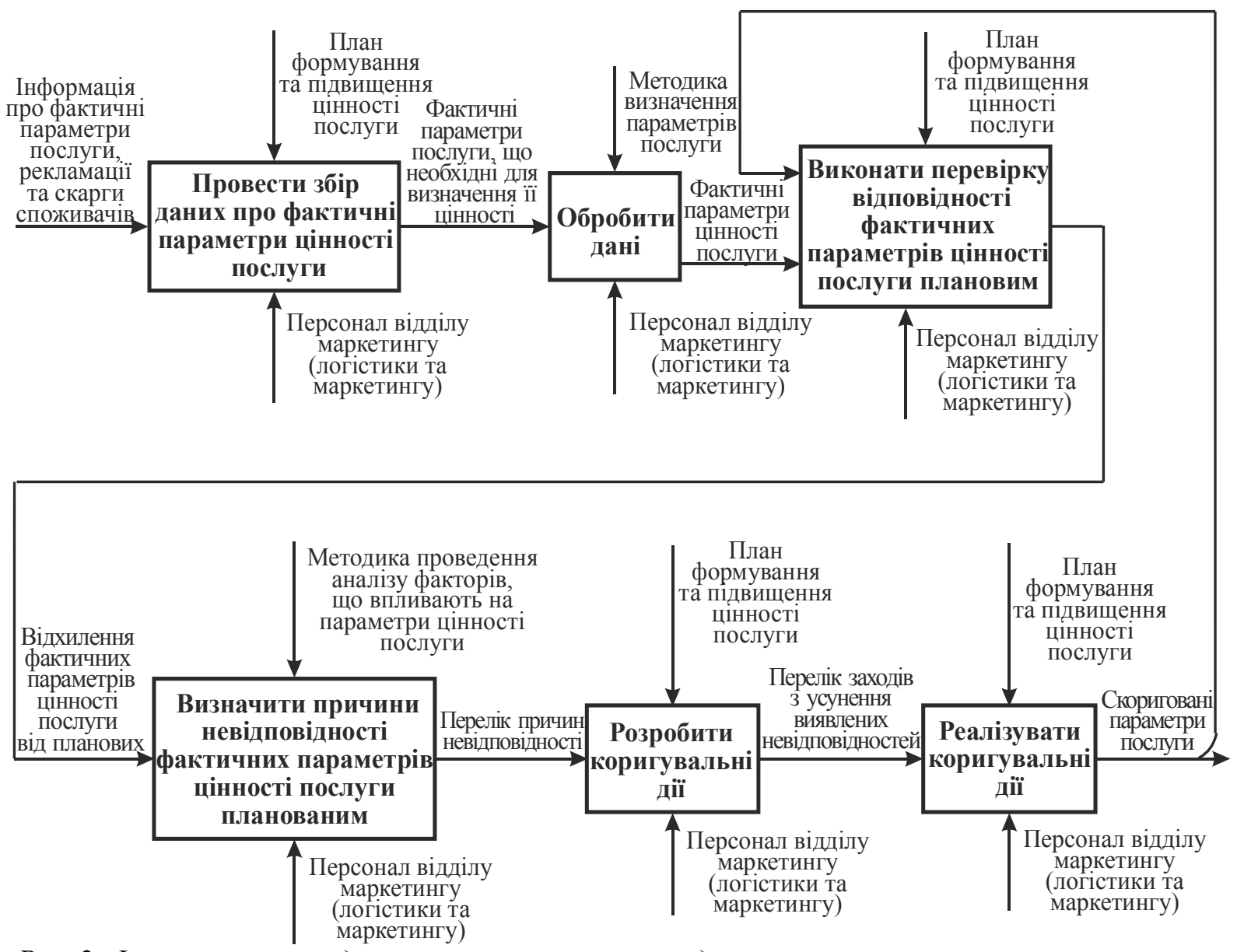

Рис. 2. Функціональна модель прочесу коригувальних дій в системі управління иінністю послуг пасажирського автомобільного транспорту 
Наступним кроком $є$ перевірка відповідності фактичних параметрів цінності послуги плановим 3 метою визначення параметрів, які мають відхилення, що виходять за межі допустимих. «Входом» зазначеного підпроцесу $\epsilon$ «вихід» попереднього підпроцесу. Управління підпроцесом здійснюється на підставі плану формування та підвищення цінності послуги [11]. «Виходом» цього підпроцесу $\epsilon$ рівень відхилення фактичних параметрів цінності послуги від планових.

На наступному етапі здійснюється визначення причин цього відхилення. «Входом» даного підпроцесу $\epsilon$ «вихід» попереднього підпроцесу. Управління підпроцесом здійснюється на підставі методики проведення аналізу факторів, що впливають на параметри цінності послуги. Для параметрів цінності, що $\epsilon$ технікоексплуатаційними показниками послуги, зазначений аналіз виконують згідно [14]. Так, на параметр цінності послуги «швидкість доставляння» впливають такі фактори: тип автобуса, його місткість, динамічні якості; довжина маршруту; тип дорожнього полотна, його стан; інтенсивність руху, склад потоку; режим управління, умови праці водіїв; пасажиропотік i наповнення автобусів. «Виходом» підпроцесу є перелік причин цих відхилень.

Далі здійснюється розробка коригувальних дій 3 метою усунення виявлених невідповідностей. «Входом» цього підпроцесу $\epsilon$ «вихід》 попереднього підпроцесу. Управління підпроцесом здійснюється на підставі плану формування та підвищення цінності послуги. «Виходом» підпроцесу $\epsilon$ перелік заходів 3 усунення відхилення фактичних параметрів цінності послуги від планових.

Завершується процес коригувальних дій в системі управління цінністю послуг реалізацією коригувальних дій та оцінкою їх ефективності. «Входом» цього підпроцесу $\epsilon$ «вихід» попереднього підпроцесу. Управління підпроцесом здійснюється на підставі плану формування та підвищення цінності послуги. «Виходом» підпроцесу $є$ скориговані параметри послуги. Ефективність коригувальних дій визначається відсутністю невідповідностей фактичних параметрів цінності послуги планованим. Тому, для оцінки ефективності коригувальних дій в моделі передбачений зворотній зв'язок інформація про скориговані параметри послуги поступає в підпроцес перевірки відповідності фактичних параметрів цінності послуги плановим. В разі, якщо скориговані параметри послуги відповідають запланованим, коригувальні дії вважаються ефективними. В іншому випадку здійснюється виконання розглянутих вище етапів (визначення причин невідповідності фактичних параметрів цінності послуги запланованим; розробка коригувальних дій; реалізація коригувальних дій). В разі повторного виявлення невідповідності аналізується правильність визначення причин невідповідності фактичних параметрів цінності послуги планованим.

Висновок. Таким чином обгрунтовано та розроблено процеси формування попереджуючих та коригувальних дій в системі управління цінністю послуг пасажирського автомобільного транспорту на основі процесного підходу та методології IDEF0. Пропоновані процеси враховують особливості формування цінності цих послуг та дозволяють своєчасно запобігти потенційні причини відхилення фактичних параметрів цінності послуги від запланованого рівня та коригувати фактичні iі параметри при виявленні зазначених відхилень.

\section{СПИСОК ЛІТЕРАТУРИ}

1. Бест Р. Маркетинг от потребителя / Роджер Бест; [под. ред. П. Миронова]; [пер. с англ. С. Памфилова и Н. Брагиной]; Стокгольмская школа экономики. - М.: Манн, Иванов и Фербер, 2008. - 760 с.

2. Мельник Л.Г. Маркетингова цінова політика: навчальний посібник / Л.Г. Мельник, Л.В. Старченко, О.І. Карінцева. Суми: «Університетська книга», 2007. - 240 с.

3. Длігач А.О. Маркетингова цінова політика: світовий досвід, вітчизняна практика: навчальний посібник / А.О. Длігач. - К.: «Професіонал», 2006. - 304 с.

4. Шинкаренко В.Г. Обгрунтування споживчої цінності послуги пасажирського автомобільного транспорту / В.Г. Шинкаренко, С.А. Легкий // Економіка транспортного комплексу: збірник наукових 
праць. - Х.: ХНАДУ. - 2012. - Вип. 19. - С. 68-79.

5. Калда К.О. Управління цінністю авіатранспортної послуги. Автореферат дисертації на здобуття наукового ступеня кандидата економічних наук. Спеціальність 08.00.04 «Економіка та управління підприємствами» (за видами економічної діяльності). / К.О. Калда. - К.: НАУ, 2009. $21 \mathrm{c}$.

6. ДСТУ ISO 9000:2009. Системи управління якістю. Основні положення та словник термінів (ISO 9000:2008, IDT). - К.: Держстандарт України, 2008. - 26 с. (Національний стандарт України).

7. Управління

якістю інфокомунікаційних послуг: навчальний посібник / [С.Г. Борисевич, В.Г. Буряк, І.В. Станкевич и др.]. - Одеса: ОНАЗ, 2010. - 272 c.

8. Лебединець В.О. Організація коригувальних та запобіжних дій в межах фармацевтичної системи якості / В.О. Лебединець // Управління, економіка та забезпечення якості в фармації. - 2013. - № 1. - C. 30-35.

9. Зубояров О.Р. Процесс управления корректирующими и предупреждающими действиям на металлургическом предприятии / О.Р. Зубояров // Экономика региона. - 2010. - № 4. - С. 215-220.

10. Шинкаренко В.Г. Формування системи управління цінністю послуг пасажирського автомобільного транспорту / В.Г. Шинкаренко, С.А. Легкий // Економіка транспортного комплексу: збірник наукових праць. - Харків: ХНАДУ. - 2015. - Вип. 25. C. 135-144.

11. Шинкаренко В.Г. Формування цінності послуг пасажирського автомобільного транспорту / В.Г. Шинкаренко, С.А. Легкий // Економіка транспортного комплексу: збірник наукових праць. - Харків: ХНАДУ. - 2015. - Вип. 26. C. 109-121.

12. РД IDEF0-2000. Методология функционального моделирования. - М.: Издательство стандартов, 2000. - 75 с.

13. Кузьмин А.В. Теория систем автоматического управления: учебник / А.В. Кузьмин, А.Г. Схиртладзе. - Старый Оскол: THT, 2014. - 222 c.

14. Спирин И.В. Организация и управление пассажирскими автомобильными перевозками: учебник / И.В. Спирин. - 5-е изд., перераб. - М.: «Академия», 2010. - 400 с.

Рецензент д.е.н., професор ХНАДУ Шинкаренко В.Г. Експерт редакційної колегії к.е.н., доцент УкрДУЗТ Токмакова І.В.

\title{
УДК 658.001.42 (477)
}

\section{ФОРМУВАННЯ СИСТЕМИ СТРАТЕГІЧНОГО КОНТРОЛІНГУ}

\author{
Підопригора I.В., к.е.н, доцент, \\ Мінка В.Ф., к.е.н, доцент (УкрДУЗТ)
}

В статті доведено, щчо під контролінгом слід розуміти комплексну систему підтримки управління організаиією, спрямована на координаиію взаємодї систем менеджменту $i$ контролю їх ефективності. 3'ясовано, що в економічній теорії існує декілька різновидів контролінгу. В сучасних умовах функціонування велике практичне значення для вітчизняних підприємств має виділення стратегічного $i$ оперативного контролінгу. Дослідивши особливості стратегічного управління та стратегічного контроллінгу було запропоновано формування трирівневої системи стратегічного контроллінгу для однобізнесових підприємств та чотирирівневої системи - для мультибізнесових підприємств.

Ключові слова: контроллінг, стратегічний контроллінг, підприсмство, конкурентоспроможність, система. 